\title{
BUREAUCRACY REFORM STRATEGY OF THE LOCAL GOVERNMENT IN CIMAHI CITY TOWARDS GLOBALIZATION ERA
}

\author{
Titin Rohayatin, Agus Subagyo, Agustina Setiawan \\ Lecturers at Faculty of Social and Political Sciences \\ University of Jenderal Achmad Yani, Cimahi \\ titin.rohayatin@yahoo.com
}

\begin{abstract}
The bureaucratic reform strategy of local government is an effort to strengthen the region and respond to challenges in the era of globalization. Bureaucracy reform is not just simplifying the bureaucratic structure but changing the mindset and bureaucratic culture in governance management. The reality of bureaucratic reform is still experiencing obstacles and slowness such as bureaucratic behavior has not changed to a better direction. This is also evident from the increasing number of apparatus in the case of corruption, and the performance of the government in the service has not been optimal even though the decentralization principle has been realized, the bureaucratic reform program has been provided but not yet realized properly. Although performance indicators are available, there is still poor performance. So that the reform which contains the conceptual model of bureaucratic reform as a foundation in reforming the structure, bureaucratic culture and bureaucratic reform strategy becomes very important.

The formulation of problems of this research is on issues about how the institutions, management and behavior of the government bureaucracy, and why bureaucratic reform is needed within the scope of the regional government. The purpose of this research is to describe and analyze the institutional, management, bureaucratic ethics and analyze the reasons for the need for bureaucratic reform. The research method used descriptive analysis with qualitative approach. Data collection techniques used literature and field studies (observation and interview). While data analysis techniques used data recap, data reduction, data presentation, verification and inference. The object of this research is the apparatus of local government in Cimahi, with purposive sampling technique.

The results of the research showed that institutional, management through the implementation of governmental management has not reached the optimal value. The reason for the need for bureaucratic reform can be said specifically from the work culture of bureaucracy has not supported professional bureaucracy, the high practice of corruption, collusion, nepotism (KKN); and the quality of service that has not fulfilled public expectations, for instance the low discipline and professional ethics of employees, and the level of efficiency, effectiveness and productivity of government bureaucracy is still bad.
\end{abstract}

Keyword: strategy, Reform of government bureaucracy, globalization. 


\section{Introduction}

\subsection{Background of Research}

Government bureaucratic reform is interpreted as a major change in the paradigm of governance that leads to organizations/institutions management, Human Resources, services, and accountability. According to Samin, reform can be defined as a movement to change the form and behavior of an order, because the order is no longer liked or not in accordance with the needs of the times, either because it is inefficient, unclean or undemocratic. ${ }^{1}$

Government bureaucracy is a very vital element in determining the direction to achieve success in the administration of the country. From Thoha's perspective, bureaucracy is a government or community management in writing, planned, neatly documented and carried out by educated and civilized people. ${ }^{2}$ With the rapid advancement of information and communication technology and increasingly fierce global competition, people are increasingly sensitive to the performance of government bureaucracies and are very concerned about improving their quality of life. The quality of performance of the government bureaucracy will determine the level of public trust in the government. Based on Asropi's opinion, the main issue of bureaucratic reform is the HR problem, both concerning the leadership commitment, quality and morality of HR, the system as a determinant of the performance of regional government bureaucracy reforms that have not been satisfactory. ${ }^{3}$

Government bureaucratic reform is part and effort to strengthen the state because through bureaucratic reform the role of government is redefined to answer challenges, because bureaucratic reform does not merely simplify bureaucratic structures but can change the mindset and pattern of bureaucratic culture for various roles in governance. Furthermore, Asropi said that Culture has a big influence on the performance of bureaucratic reform and bureaucratic culture is very important for government bureaucratic reform in the region. ${ }^{4}$

Government bureaucratic reform is very urgent to do when it is associated with various changes in the context of the globalization era, including changes in the paradigm of power which was originally in the form of centralization. In this reform era, there have been significant changes in systems and power relations to become more democratic and more distributed through the principles of decentralization.

Government bureaucratic reform has been proclaimed since the reform era exists, but this has experienced obstacles and delays in reality such as changes in bureaucratic behavior that have not seemed to change in a better direction, the increasing number of officials or bureaucrats involved in corruption, service to the community, both at the center and in regions that have not shown optimal performance, even though the principle of decentralization has been realized. There are many programs that are designed to

\footnotetext{
${ }^{1}$ Samin Ramzi, Reformasi Birokrasi. Jurnal Fisip Umrah Volume 2 Nomor 2, 2011 hlm 172.

${ }^{2}$ Thoha Miftah, Reformasi Birokrasi Publik Pasca Orde Baru. Perubahan Tanpa Grand Design. Jurnal Ilmu Sosial dan Ilmu Politik, Volume 5 Nomor 3, 2000 hlm 79.

${ }^{3}$ Asropi, Budaya Inovasi dan Reformasi. Jurnal IlmuAdministrasi, volume V Nomor 3, September 2008. Hlm 2

${ }^{4}$ Ibid.,hlm 2
} 
achieve bureaucratic reform, but in its implementation, there are still many Regional Governments as the spearhead of service to the community that have not been realized properly.

Likewise, when talking about performance issues, this can still be said to have not been implemented properly, even though performance indicators are available. Regional Government bureaucratic reforms contain a conceptual model of bureaucratic reform as the basis for reforming the structure and culture of Regional Government bureaucracy. It is the reason why the bureaucratic reform strategies which contains steps to improve bureaucracy becomes very important.

In the reform era and in the face of this era of globalization, government bureaucratic reforms including Regional Government are very much needed as a basis for reforming the structure and culture of bureaucracy in Indonesia. Efforts to reform the regional bureaucratic culture and its steps in the era of globalization are very important and strategic. This bureaucratic reform is expected to be used as a foundation for setting the direction and basis of policy in developing programs in the Regional Government.

\subsection{Special Objective.}

The objective of research is as follows:

a. Mapping the existing conditions of the Regional Government bureaucracy, both in terms of institutions, management, performance and culture of regional bureaucracy as well as ethics and bureaucratic behavior.

b. Analyzing the reason why Regional Government bureaucratic reform strategies are needed,

c. Analyzing the need to reform bureaucratic structures and procedures in accordance with the democratic paradigm and decentralization in the era of globalization,

d. Describing the inhibiting factors for regional government bureaucratic reform.

e. Developing general guidelines for Regional Government bureaucratic reform strategies as a guide for restructuring structures both in terms of institutions, management, performance and bureaucratic culture at the regional level, especially the Cimahi City Regional Government.

\subsection{The Urgency of the Research}

The main thing in the implementation of the Regional Government Bureaucracy Reform Strategy Research Towards the Era of Globalization is mapping the existing conditions of the Regional Government bureaucracy both in terms of institutions, management and bureaucratic ethics and analyzing why bureaucratic reform is needed in the Regional Government order, analyzing the need for appropriate bureaucratic structures and procedures with the democratic paradigm and decentralization, as well as the inhibiting factors for reforming the Regional Government bureaucracy.

Furthermore, the formulation of general guidelines for bureaucratic reform is used as a strategy to reform the Regional Government bureaucracy which will later be used as a guide for reforming the structure, performance, behavior and culture of 
bureaucracy in the regions. The preparation of general guidelines for bureaucratic reform as a strategy for bureaucratic reform needs to be done to map back the stages and steps of regional government bureaucratic reform.

\subsection{Findings/The Targeted Innovations}

The results of this study are expected to have and explain in detail about:

a. The mapping of the Regional Government bureaucracy in terms of institutions, management, performance and culture of regional bureaucracy and ethics/ bureaucratic behavior.

b. The reason for the need for a bureaucratic reform strategy

c. The need to reform bureaucratic structures and procedures in accordance with the paradigm of democracy and decentralization in the era of globalization

d. The inhibiting factors for regional government bureaucratic reform

e. The composition of the Regional Government bureaucracy reform strategy will later serve as a guide to reform the structure, performance, behavior and culture of bureaucracy in the region. The preparation of general guidelines for bureaucratic reform as a strategy for bureaucratic reform needs to be done to map back the stages and phases of regional government bureaucratic reform.

\section{Literature Review}

\subsection{Government Bureaucratic Reform}

Government bureaucratic reform is interpreted as a major change in the paradigm of governance that leads to the organizations/institutions, management, human resources, services, accountability, legislation law and mindset of bureaucratic reform of Regional Government. Samin has explained that reform can be defined as a movement to change the form and behavior of an order, because the order is no longer liked or not in accordance with the needs of the times, either because it is inefficient, unclean or undemocratic. ${ }^{5}$

Samin also defined bureaucracy as government or community management in writing, planned, neatly documented and carried out by educated people. ${ }^{6}$ One of the main factors that plays a role in the realization of clean and good governance is Bureaucracy. In such an important position and role in managing public policies and services, the bureaucracy greatly determines the efficiency and effectiveness of governance and development.

Samin noted that bureaucratic reform can be done through a professional administration approach and a minimalist approach. Professional administration is a sociological approach that views bureaucracy as part of the type of organization. The minimalist approach bases its assumption on how bureaucracy should work. This approach produces bureaucracy that gives an employee a hierarchical stratification system where people are employed only for wages and salaries. ${ }^{7}$ In the context of

\footnotetext{
${ }^{5}$ Samin Rumzi, Reformasi Birokrasi. Jurnal Fisip Umrah Volume 2 Nomor 2, 2011 hlm 172

${ }^{6}$ Ibid., hlm 172

${ }^{7}$ Ibid., hlm 173
} 
government bureaucracy related to public affairs if the bureaucracy provides public services properly, the bureaucracy can show its indications of bureaucratic behavior. Samin explained that bureaucratic reform in the context of the development of a government administration system must pay attention to democracy and empowerment, service, transparency, participation, partnership, decentralization, consistency of policies and legal certainty. ${ }^{8}$

Government bureaucratic reform in the reform era marked a change in government order towards decentralization which began in 1999. The consequences of adopting decentralization in the implementation of regional autonomy have changed the entire order and function in the bureaucracy in the New Order era to the kind of government should be in the reform era, such as the desire to uphold democracy properly. According to Thoha, there are three things that quite influence various institutional changes, which illustrate the conditions underlying the process of change from New Order to reform era, namely the desire to uphold democracy well, the political system change from single majority to multi-party and the process of developing information technology and global economic competition. ${ }^{9}$

Democratic public bureaucracy means that in government institutions, democratic principles can be developed, government institutional structures should not be separated from public control, in this case the role of the people in democratic governance is carried out when forms of government will be formed. The change in the political system from the single majority to multi-party means that changes in the political system are developing in a pluralistic direction.

In this condition, with the existence of a multi-party-political system, it would be hard to imagine the existence of a single majority that controls the government, at least, this encourages the formation of coalitions in government that combine the aspirations of several political parties. One sign of the progress of the era and global change is the implementation of work methods in a bureaucracy by using information technology, this kind of work makes the bureaucracy become more flexible and will also encourage organizations to become a paperless organization.

Borderless bureaucracy gives a new face to the bureaucracy that no longer strictly follows the hierarchical line. The organizational structure that is ad-hoc, committee and matrix become the model of the upcoming bureaucratic organization. Furthermore, Thoha explained that the paradigm shift of the government bureaucracy that information technology is now something that is difficult to avoid, it means that in the government service, information technology must be the main activity in every process and solution related to government management. ${ }^{10}$

The main problem of bureaucratic reform is the problem of Human Resources (HR) as the executor of the bureaucracy, both concerning leadership commitment and the quality and morality of $\mathrm{HR}$, including bureaucratic behavior including bureaucratic

\footnotetext{
${ }^{8}$ Ibid., hlm 174-176

${ }^{9}$ Thoha Miftah, 2000. Reformasi Birokrasi Publik Pasca Orde Baru. Perubahan Tanpa Grand Design. Jurnal Ilmu Sosial dan Ilmu Politik, Volume 5 Nomor 3, 2000, hlm 79

${ }^{10}$ Ibid., hlm 83
} 
performance, many strategies that have been planned but the results are not satisfactory, for example, such as culture bureaucratic innovation. Bureaucratic reform is related to the culture of innovation in bureaucracy. Asropi argues that innovation is a new concept in public administration. ${ }^{11}$

The lack of popularity of the concept of innovation in the past can be understood because the character of reform is based more on the ideal bureaucratic principles of Weber. In this concept, innovation is seen as not much needed for government bureaucratic apparatus. The obligation of the government bureaucratic apparatus is to carry out established rules, even though innovation is carried out only in a culture of innovation and bureaucratic reform. Furthermore, Asropi said that the important domains in the innovation of government bureaucracy, such as sustainable development, egovernment, New product development. ${ }^{12}$

Bureaucratic reform and public service are two important elements in governance in this era of globalization towards the realization of quality and optimal public services in good governance. Bureaucratic reform is the government's commitment in the process of carrying out good governance. Komarudin stated that bureaucratic reform and governance management are directed at improving the quality of public services, the effectiveness and efficiency of institutions, ministries/ institutions in terms of corruption prevention. ${ }^{13}$ The role of the government in tackling corruption is intended to create a clean government. Rajab: "Bureaucracy as an executor/ manager in Regional Government management to have high competitiveness needs to apply the principles of good governance." 14

Good governance programs aimed at reforming governance are in fact displaying two opposing realities. In regions that have been named as best practices because they are able to reform governance and can realize several public institutions that are transparent, accountable, and responsive, it turns out that on the other hand, poor management is still found. Jani stated that in order to manage a good governance system, the principles of good governance need to be applied in the mechanism of Regional Government." governance was agreed as part of a new institutional design to encourage a collaborative process between market entities, the state and civil society to create development innovations and encourage bureaucratic performance to work neutral and serve the public interest. Personal: good governance that is normatively believed to be a design to manage so that the market works in the public interest." ${ }^{16}$

\footnotetext{
${ }^{11}$ Asrofi, Budaya Inovasi dan Reformasi. Jurnal Ilmu Administrasi, volume V Nomor 3. September 2008. Hlm 246

${ }^{12}$ Ibid., hlm 253

${ }^{13}$ Komarudin, Reformasi Birokrasi dan Pelayanan Publik. Jurnal Sekretariat Negara RI. Nomor 20, 2011, hlm 148

${ }^{14}$ Rajab Budi, Birokratisme, Good Governance dan Demokratisasi. Analisis CSIS Volume 14 No4, Desember 2012

15 Jani Luky, Implementasi Local Governance : Menjelaskan Paradoks. Analisis CSIS Volume 42 No 1, Maret 2013.

${ }^{16}$ Pribadi Airlangga, Paradoks Inovasi Dalam Praktek Good Governance di Kota Surabaya. Analisis CSIS Volume 42 No 1, Maret 2013.
} 
Various efforts to reform governance including Regional Government, one of which is the political process. Innovation and governance reform are aimed at increasing regional competitiveness in the management of Regional Government. Initiation, innovation and reform were born out of the expertise of the negotiation process from local non-governmental organizations and authorities, which were available to make changes. Regional Government bureaucratic reform in the era of regional autonomy and the current era of globalization are not yet maximal. Some opinions are characterized by weak aspects of human resources both in terms of morality and quality, weak bureaucratic behavior as the executor of system, and the innovations in bureaucracy reform are still not executed well.

However, researchers also see the phenomenon of government bureaucratic reform still not running optimally from several other factors, namely: weak governance management, weak institutions, weak performance of bureaucratic apparatus, bureaucratic structure and culture have not supported the implementation of governance. For this reason, the researchers in this study put more emphasis on mapping the existing conditions of the Regional Government bureaucracy both in terms of institutions, management, performance and culture of regional bureaucracy as well as ethics/bureaucratic behavior and improvement of bureaucratic structures and procedures according to the paradigm of democracy and decentralization in the globalization era.

The researcher also tried to analyze why the Regional Government bureaucratic reform strategy was needed, analyze the inhibiting factors in the Regional Government bureaucracy reform strategy and develop general guidelines for the Regional Government bureaucratic reform strategy as a guide to reform the structure, performance and culture of Regional Government bureaucracies.

\section{Methodology}

\subsection{Research Design}

Research in the Regional Government bureaucratic reform strategy towards the era of globalization requires methods, procedures in conducting research. The design of this study uses descriptive analysis method through a qualitative approach. Nasution defines "A qualitative approach in essence is to observe people in their environment or the policies they make, interact with them, try to understand their language about the world around them." ${ }^{17}$

This qualitative method can only examine several dimensions so that it cannot thoroughly explain the events in the social context in the field. With qualitative methods, researchers can find data that are feelings, norms, values, beliefs, opinions, mental and cultural attitudes adopted by a person or group of people.

\subsection{Population and Research Sample}

Goetz and Locomte (in Moleong) define that: "The population is the respondent or person who is being studied, or it can also be an object that is not human. A group of

\footnotetext{
${ }^{17}$ Nasution, Metode Penelitian Sosial, 1995 hlm 3
} 
people who are carrying out activities in certain conditions, times and environments can also be called populations." Nasution explained that: "The selection of sample units is sufficient if it has reached the level of information saturation. This means that even if the data source is added, it won't add new data." ${ }^{18}$

The population in this study is the Cimahi City Regional Government Apparatus, Sub-District Head and Village Head in Cimahi City West Java Province. Informants include: Regional Secretariat, Local Government Assistant, Regional Supervisory Board, Regional Personnel Agency, Regional Inspectorate, Regional Development Planning Agency, KPPT, Regional Revenue Service, General Section, Finance Section, SubDistrict Head and Village Head in Cimahi City Government, Java Province West. The sampling technique uses purposive sampling.

\subsection{Data Collection Technique}

Techniques for collecting data through:

1) Literature study, namely studying and analyzing literature in the form of journals, books, articles, and scientific works that have relevance to research problems.

2) Field Study through Observation; namely making observations directly on the object of research and through structured interviews; namely conducting interviews or question and answer directly with several informants, and forms of questions can develop when the interview takes place in accordance with the needs of the study.

\subsection{Data Analysis Technique}

Data analysis techniques through: Data recap; Data reduction; Data presentation; Verification and Conclusion;. ${ }^{19}$ Qualitative data analysis was carried out from the beginning of the study. As Nasution stated: "In qualitative research, data analysis must be carried out from the start. Data obtained in the field must immediately be written in the form of writing and analysis." Various ways can be done. There is not only one specific method that can be used as a guide for all research. ${ }^{20}$ In this study, the data analysis used was descriptive data analysis with a qualitative approach.

\section{Result and Discussion}

3.1. Regional Government Bureaucracy, both in terms of institutions, management, performance and culture of regional bureaucracy and ethics / bureaucratic behavior (HR Factor).

Basically, bureaucracy is a modern form of organization that is formed together to achieve common goals which are expected to be ideal organizations. The problems faced by bureaucracy are actually very complex so that bureaucratic reform is one of the

\footnotetext{
${ }^{18}$ Nasution, Metode Penelitian Sosial, 1995 hlm 3

19 Miles dan Huberman (dalam Moleong, Lexy.), 2010. Metodologi Penelitian Kualitatif (Edisi Revisi). 2010

${ }^{20}$ Nasution, Metode Penelitian Sosial, 1995 hlm 3
} 
efforts to make changes both from the elements of institutionalization (organization), management and from the elements of Human Resources (HR).

Indonesian bureaucratic reform is expected to be able to realize a bureaucratic model that can run the wheels of good governance that is democratic and in accordance with the application of the concept of decentralization. Institutionally, through bureaucratic reform, it is expected to produce institutions that are lean in function-rich structures, but there is no accumulation in one of the work units, meaning that there is equal distribution of tasks in accordance with its organizational structure and management. This institutional organization is expected to focus more on its functional position not on its structural position. The current condition in the Cimahi City Government is seen in the institutional aspect, there is still a workload / authority that has accumulated, for example, occurred at the Cimahi City Industry, Trade and Agriculture Cooperative Office in charge of several authority matters handled by one agency that are not balanced with readiness from its human resources, so that there was a buildup of authority affairs, as was the case with other agencies that took place in the City of Cimahi. Management of bureaucratic reform is expected to produce simple, easy and systematic management by applying information technology and building communication so that by improving this management, it encourages organizations to get better performance, in an accountable and transparent service process.

The City Government of Cimahi still finds it a long and convoluted service process so that people find it difficult to obtain services with these long procedures and mechanisms, and still find that SOPs in services are poorly understood because information is not available to the public with the service process. The lack of coordination between related agencies in making SOPs, for example, related to the type of service that requires the existence of a certain agency to be made a prerequisite for making permits so that this raises the length of time in the realization of the permit.

In terms of performance aspects and bureaucratic culture and ethics / bureaucratic behavior, these things are still included as part of the Human Resources (HR) factor. Reform in the aspect of HR is expected to be able to produce clean, quality bureaucratic human resources in accordance with the needs of the organization both in terms of quantity and quality (having the spirit of professionalism, competency, good character and high work ethic).

Regarding the Cimahi City Regional Government, currently the HR factor is still an interesting matter and is still the center of attention because researchers see firsthand, in number, Cimahi City Civil Servants in quantity look a lot, but when talking about placement in the organizational structure in Cimahi, it turns out that it is proven that there is still a buildup of authority that must be carried out by one agency that is not balanced with the number of personnel available. This also has an impact on service delivery and performance of government organizations.

As well as talking about the quality of human resources in Cimahi, there are still government workers that have not been matched with the level of ability and competence that should be owned, and the inappropriate placement of human resources, so this shows that the placement of human resources in regional government is not based on 
competency owned, so that this also has an impact on the process of administering the government. This happened because of the limited human resources owned by the Cimahi City Regional Government both in terms of quantity and in terms of quality.

\subsection{Analysis of why Regional Government bureaucratic reform strategies are needed.}

The strategy of regional government bureaucracy reform is one way or effort to strengthen the region in order to run the wheels of government while at the same time strengthening the role of regional governments in carrying out the concept of decentralization in accordance with the mandate of regional autonomy.

The Regional Government of Cimahi City as an autonomous region, where the regions are entitled, have the authority to manage their own households, to which they are given government affairs to manage financial resources, public service provision, and regional development. As a tangible form of all these authorities, based on the principles of efficiency and effectiveness, the regions must be able to explore the resources they have that can be used to prosper the community by providing services, increasing regional competitiveness in accordance with their potential and distinctiveness and being managed democratically and accountably.

To achieve maximum results, the Regional Government must be able to process and implement rights and obligations based on the principles of good governance. To realize good governance requires commitment and consistency from all parties, both government officials, the public and the private sector. In its implementation, it is important for good coordination from various parties. This can be seen from having high professionalism and high work ethic and morals.

In this bureaucratic reform strategy, there is also a need for behavioral changes that are in accordance with the dimensions of governance ethics, effective law enforcement and the development and application of appropriate, clear and tangible systems of accountability so that governance and development can take place efficiently and effectively, cleanly and fully responsible in accordance with the concept of good governance.

This strategy of bureaucratic reform is basically a transformation of various dimensions of values contained in the constitution. The strategy for bureaucratic reform is an answer to demands for a government that is efficient and effective and responsible and creates a clean government. This certainly requires a strategy of bureaucratic reform and human resources that has integrity, competence, and consistency in running the government including the Cimahi City Regional Government.

3.3. Analysis of the need to reform the structure and procedures of the bureaucracy in accordance with the paradigm of democracy and decentralization in the era of globalization.

Restructuring of bureaucracy is the use of authority to implement new provisions / regulations on government systems to change existing goals, structures, and procedures with the aim of facilitating the achievement of regional development goals. The 
bureaucratic arrangement or restructuring of government organizations including the Cimahi Regional Government is very important and very necessary, this is one of the future reform efforts in the context of the realization of the decentralization concept in the era of regional autonomy, one of which is through the application of Good Governance principles. This new change is in the framework of the realization of the implementation of the wheels of government and development in a professional manner, as well as the realization of a system and process of the government bureaucracy which acts as a forum to realize the goals of the Cimahi City Regional Government.

Talking about bureaucratic reform can show organizational improvement / bureaucratic reform so that quality organizations that are focused in the future can be formed or plan improvements to existing systems / improvements to government processes that realize accountable and transparent government processes. The demands of bureaucratic reform are one of them is reforming the structure and procedures of bureaucracy where government organizations are oriented to the quality of the organization by showing the performance of the organization for example through the quality of Human Resources.

The steps that can be taken in this improvement include:

1) Clarifying the aims and objectives of the organization, for example through the organization's Vision and Mission, including the vision and mission of the Cimahi City Regional Government, must be able to show the direction of policy and the direction of regional development in Cimahi City.

2) Implement the consequences of organizational performance, for example the application of clear basic tasks and organizational functions with an easy and simple mechanism through the establishment of an organization's Standard Operating Procedure (SOP).

3) Creating accountability of government organizations to the public, such as running the wheels of government accountably and promoting the principle of transparency.

4) Empowering organizations and organizational actors (HR) for example through developments or innovations to develop regional progress.

5) Change the behavior and way of thinking of employees / organizational actors such as adhering to the concept of service rather than being served in accordance with the essential functions of government that one of them has a service function.

With the improvement of the organizational structure and bureaucratic procedures, it is expected that the Regional Government of Cimahi City can run a democratic government and in accordance with the concept of decentralization as a mandate of regional autonomy regulated by the Law on Regional Government.

\subsection{Inhibiting factors for bureaucratic reform of the Cimahi City Regional Government}

In general, the obstacles to Cimahi's Regional Government bureaucratic reform are as follows: 
1) Institutional aspects (organization); in the institutional aspect (organization) of Cimahi City local government, there is still overlapping of authority between agencies, there is still a debate about the limits of the authority of each related agency. For example, one of the things that happened to the Cimahi City Transportation Service was with the Police, especially the traffic rules.

2) Management Aspects; in the management aspect of the Cimahi City Government there is still a lack of SOP services, and there are still many people who feel that when dealing with the government related to the service process they must go through lengthy procedures and long service. This shows that there is no easy and simple service process.

3) Aspects of Human Resources; Human resources that determine the performance of the bureaucracy are not only seen in terms of quantity but also in terms of quality, meaning that the performance of bureaucracy is determined by the ability of human resources to carry out their functions. Current conditions in Cimahi City are still limited in terms of quantity and quality. In one of the work units in the Cimahi Regional Government, there are still several matters handled by more than one unit, ideally one sector is handled by a Sub-Division Head so that the work unit's performance will be more optimal. The placement of employees is not appropriate, so this has an impact on the implementation of service processes that are not in accordance with their competencies.

\section{Conclusion and Suggestion \\ 4.1 Conclusion}

From the description of the discussion it can be concluded as follows:

1. From the institutional, management and HR aspects in the Cimahi City Regional Government, it has not been fully said to be good because of each of these aspects illustrates the problems that require improvement in each of these aspects.

2. The inhibiting factor in bureaucratic reform in the Regional Government of Cimahi City also illustrates the institutional, management and HR aspects.

3. The absence of a City Regional Government bureaucracy reform strategy formulated in the form of policy.

\subsection{Suggestion}

From the description of the conclusions, the suggestions given are as follows:

1) There needs to be improvement on the institutional, management and HR aspects at the level of the Cimahi City Regional Government.

2) It is necessary to formulate a strategy for bureaucratic reform in various aspects, especially the institutional, management and HR aspects. 


\section{BIBLIOGRAPHY}

Asropi. (2008). Budaya Inovasi dan Reformasi. Jurnal Ilmu Administrasi, volume V Nomor 3. September 2008. Halaman $246-255$.

Jani Luky. (2013). Implementasi Local Governance: Menjelaskan Paradoks. Analisis CSIS Volume 42 No 1, Maret 2013. ISSN1829-5908.

Komarudin. (2011). Reformasi Birokrasi dan Pelayanan Publik. Jurnal Sekretariat Negara RI. Nomor 20.

Nasution. 1995. Metode Penelitian Sosial

Moleong, Lexy. (2010). Metodologi Penelitian Kualitatif (Edisi Revisi). PT. Remaja Rosdakarya. Bandung

Pribadi Airlangga. (2013). Paradoks Inovasi Dalam Praktek Good Governance di Kota Surabaya. Analisis CSIS Volume 42 No 1, Maret 2013. ISSN1829-5908.

Rajab Budi. (2012). Birokratisme, Good Governance dan Demokratisasi. Analisis CSIS Volume 14 No4, Desember 2012. ISSN1829-5908

Samin Rumzi. (2011). Reformasi Birokrasi. Jurnal Fisip Umrah Volume 2 Nomor 2 halaman 172-182.

Thoha Miftah. (2000). Reformasi Birokrasi Publik Pasca Orde Baru. Perubahan Tanpa Grand Design. Jurnal Ilmu Sosial dan Ilmu Politik, Volume 5 Nomor 3 halaman $246-255$. 